\title{
Zooplankton of the Torrential River Chenab at Akhnoor, Jammu, India, and Its Comparison with Earlier Findings
}

\author{
Sunt P. Singh Dutta \\ Department of Environmental Sciences, University of Jammu, Jammu, India \\ Email address: \\ duttasps@gmail.com \\ To cite this article: \\ Sunt P. Singh Dutta. Zooplankton of the Torrential River Chenab at Akhnoor, Jammu, India, and Its Comparison with Earlier Findings. \\ American Journal of Applied Scientific Research. Vol. 7, No. 3, 2021, pp. 46-55. doi: 10.11648/j.ajasr.20210703.13
}

Received: April 28, 2021; Accepted: June 24, 2021; Published: July 22, 2021

\begin{abstract}
The river Chenab, river of the Indian sub-continent in north-western India and north-eastern and eastern Pakistan, has mostly torrential flow in India. It drains Jammu region of the Union Territory of Jammu and Kashmir, India, and after passing through Pragwal wetland, Akhnoor, enters into the broad alluvial lowlands of Punjab province, Pakistan. The present communication highlights the origin and seasonal qualitative and quantitative fluctuations of zooplankton of the Himalayan river Chenab at Akhnoor, Jammu. Zooplankton of the river Chenab has its origin mainly in rockpools, in tributaries joining upstream Akhnoor and a part is periphytonic (epilithic/ epibenthic). A total of 28 zooplanktonic species belonging to 25 species of protozoa, gemmules of 2 species of Porifera (Spongilla lacustris and Eunapius carteri) and 1 species of Turbellaria (Planaria sp.) were noticed. There is almost no change in composition of zooplankton from the earlier observations at Akhnoor. Whereas, its slow moving and polluted segment in Pakistan is dominated by metazoans. Qualitatively and quantitatively zooplankton remained irregular and low during monsoon and post monsoon months. Analysis of coefficient of correlation of zooplankton with water quality parameters is almost insignificant.
\end{abstract}

Keywords: Zooplankton, The River Chenab at Akhnoor, Comparison with Earlier Findings

\section{Introduction}

Hydrological conditions in torrential rivers arising from steep gradient and torrential flow, irregular water discharge, turbulent mixing, absence of pools and slack water, feeding interference from high load of suspended matter and population dilution (upstream and tributary inputs) impose stressful conditions on aquatic organisms, including zooplankton. Zooplankton biomass in rivers is inversely related to discharge [1-3]. The net effect of these processes is absence or low diversity of metazoans and planktonic community can be found among the bacteria, phytoplankton and protozoans [4-8]. As main consumers of bacterial production, the protozoans play an important role among the plankton. They are essential component of the pelagic food web and, thus, of pivotal importance in the degradation of organic matter in aquatic ecosystems. In addition, several species of ciliates and flagellates are able to consume algae and protozoans and could perform similar functions in the food web as the metazoans [9-11]. Poor availability of phytoplankton as a food resource may constrain zooplankton
[2] and net primary productivity may be limited by turbidity, turbulence and helical flow which transport algae to the aphotic zone for extended periods [12]. Planktonic studies in the Himalayan and Shivalik lotic waters in Jammu region are scarce [13-20]. The present study was undertaken in the river Chenab at Akhnoor, Jammu, to find out any change in zooplanktonic composition from the earlier observations in the area and has revealed no change in protozooplanktonic dominance [18]. Zooplanktonic composition in torrential Indian segment of the river Chenab has also been compared and discussed with its pooled, slow moving and polluted, at various places, segment in Pakistan. The study will provide a baseline data for limnologists to undertake studies in streams and rivers of Jammu region.

\section{Topography and Materials and Methods}

\subsection{Topography}

The river Chenab, an important Himalayan tributary of the 
river Indus, draining Jammu region flows through India and Pakistan. It is formed by the confluence of Chandra and Bhaga streams at Tandi, $8 \mathrm{kms}$ south west of Keylong, in the Lahul and Spiti district in the Himachal Pradesh. At Panji, the river enters Jammu region of the Union territory of Jammu \& Kashmir, India, at an elevation of 1828 mtrs above mean sea level. After passing through Kishtwar, Thathri, Doda, Ramban, Reasi and Pargwal, it enters into the broad alluvial lowlands of Punjab province, Pakistan, and joins the river Indus near the city of Uch Sharif. For the present planktonic study, 3 stations, between a distance of about $6 \mathrm{kms}$., were selected at Akhnoor (Figures 1-3).

Station I (Ambarain): The area is of historical importance and there is no biotic interference (Figure $1 \mathrm{a} \& \mathrm{~b}$ ).

Station II (Namandar): There is entry of sewage drain and burning of dead bodies and immersion of ashes in the upstream area. Bathing and washing of clothes is also seen in the area. A good number of rocks and rock pools are present. During winter migratory birds are seen in good number (Figure 2 a \& b).

Station III (Dhoomi): Water flow is fast. The river depth is more than $20 \mathrm{ft}$. There are a good number of rocks having surface rock pools. The area is under army control and free from any type of anthroprogenic interference (Figure $3 \mathrm{a} \& \mathrm{~b}$ ).

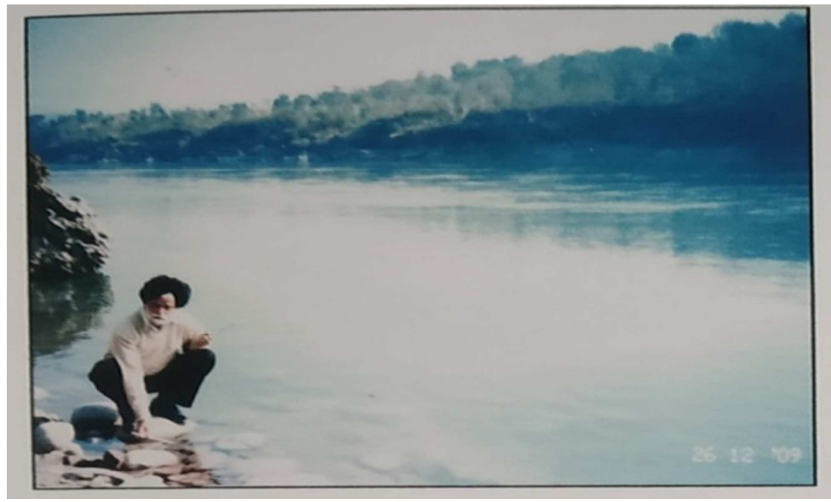

(a)

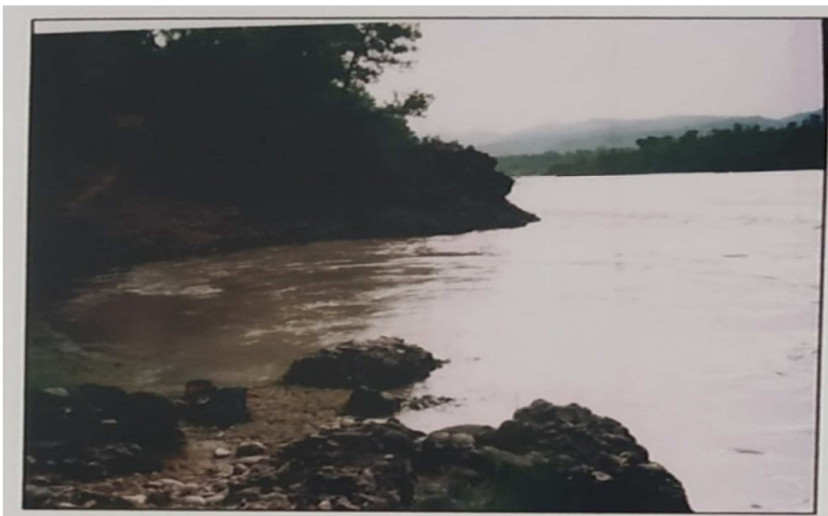

(b)

Figure 1. General view of Station I of the river Chenab, Akhnoor: (a) Winter and (b) Monsoon.

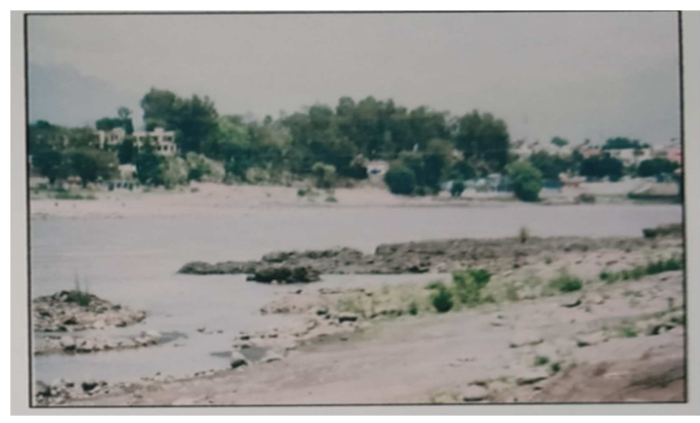

(a)

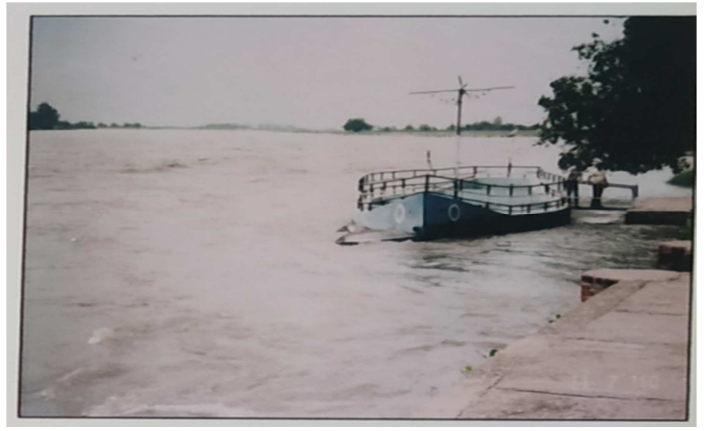

(b)

Figure 2. General view of Station II of the river Chenab, Namandar: (a) Winter and (b) Monsoon.

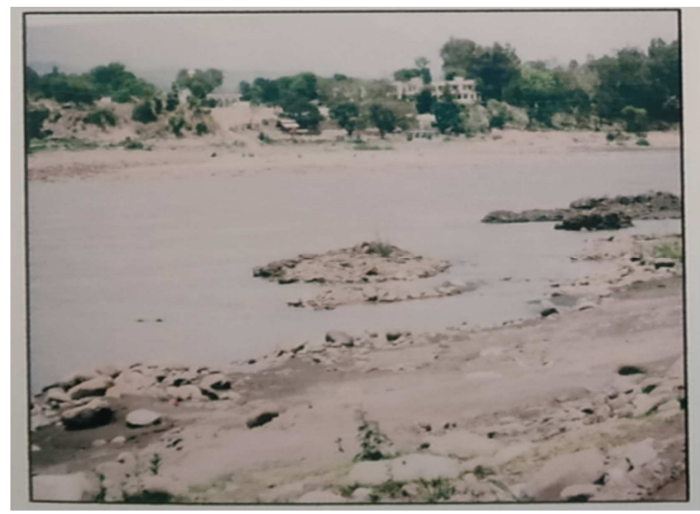

(a)

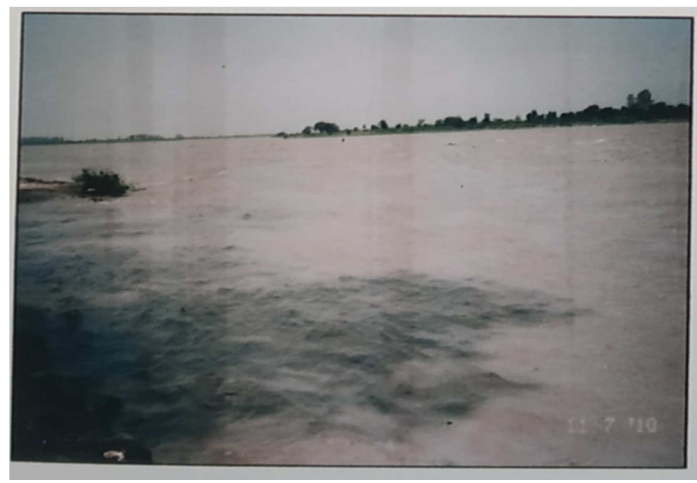

(b)

Figure 3. General view of Station III of the river Chenab, Dhoomi: (a) Winter and (b) Monsoon. 


\subsection{Sampling and Analysis of Zooplankton}

For zooplanktonic study, 20 litres of water was collected at each station, filtered through a planktonic net (No. 25) and identified [21-25]. For quantitative planktonic analysis, Sedgewick rafter counting cell was used. The results are represented as the mean of three stations.

\section{Results and Discussion}

\subsection{Origin of Plankton}

Different explanations have been given for the origin of lotic water plankton. Kofoid* [26] concluded that the plankton of the Illinois River channel is not derived directly from the tributaries but largely from the impounding backwaters and that at low water stages, it is almost exclusively indigenous in the channel, itself. Galstoff* [27] came to a similar conclusion concerning upper Mississippi river. According to Galstoff* [27], Schutt claimed that the Amazon river plankton arises in the upper tributaries and is not developed in the main portion of the river. Kreiger* [28] documented that the organisms which make up river plankton originate from (I) the area surrounding the head waters of the river (II) the heleoplankton from pools along the river (III) the limnoplankton from lakes along the river and (IV) tributary streams and drains. Butcher* [29] has shown that in rivers, which he studied, all of the planktonic organism, with very few exceptions, can be found at one time or another on the river bed and entangled among the submerged and littoral macrophytes. The current washes free from attachment individuals and portions of colonies, thus, adding them to the plankton. Brown et al. * [30] from their several zooplanktonic surveys in streams and observation of other workers showed that retention time could be favourable for planktonic growth Saunders and Lewis [1] observed that areas of minimum flow in rivers are zones of small pulses of zooplanktonic abundance from where recruitment in waters takes place. According to Basu and Pick [31], Reckendorfer et al. [32], Baranyi et al, [33] and Basu et al. [34], compared to channel sites, slack water habitats have faster population growth for plankton.

* cited from Welch (1952)

Due to steep gradient and fast currents, vertical mixing and drifting of water, turbid water throughout the year (except during winter), lack of slack water habitat, absence of lakes in catchment, unstable bottom dominated by boulders and rocks and absence of macrophytic vegetation, origin and survival of metazooplankton in main portion of the river Chenab, in the Indian segment, is not possible and is supported by their absence, except Planaria. Zooplankton at Akhnoor is represented by protozoans, sponges and Turbellaria and have their origin (i) mainly in surface rockpools present along the river (ii) a part is periphytonic (epilethic/ epibenthic) and (iii) in tributaries joining the river at different places.

Planktonic analysis of six pools on the left bank of the river Chenab, at Dhoomi, Akhnoor, has revealed a rich zooplanktonic diversity represented by protozoans, poriferans, rotifers and turbellarians [35]. Rotifers (Lepadella, Philodina and Rotaria genera) found in these pools are totally absent in the main river. Ciliates in these rock pools are represented by Paramecium, Chilodonella, Euploteus, Stylonychia and Vorticella genera. In the river, only genus Paramecium has been observed. Zooplankton growing in these pools are carried into the river during floods and flushing during rains. Some of the groups like rotifers and ciliate protozoans are unable to survive in the main river and have not been noticed during the present study.

\subsection{Qualitative Composition and Quantitative Analysis of Zooplankton}

Monthly, two years viz March, 2009- February 2011, mean results of zooplanktonic analysis at three experimental stations in the Akhnoor area have been tabulated in Tables $1 \& 2$.

\subsubsection{Qualitative Composition}

Zooplankton, qualitatively, comprising of 28 species has shown the presence of 25 species of Protozoa viz. 21 species of Rhizopoda (Arcella vulgaris, A.discoides, Centropyxis ecornis, C.aculeata, C.aerophila, C.constricta, C.arcelloides, Difflugia tuberculata, D.acuminata, D.lebes, D.oblonga, D.corona, Difflugia sp., D.urceollata, D.bacillarifera, D.rubescens, Lesquersia, sprialis, L. modesta, Plagiopyxis sp, Nebela $s p$ and Euglypha sp), 2 species of Mastigophora (Euglena sp. and Phacus sp.) and one species of Ciliata (Paramecium sp.) and Suctoria (Haltaria sp.); gemmules of 2 species of Porifera (Spongilla lacustris and Eunapius carteri) and one species of Turbellaria (Planaria sp.). There is total absence of metazoans, except Turbellaria. Present qualitative composition of zooplankton is similar to the observations made in the year 2004-2005 and reported [18] from the area (Arcella sp., Centropyxis ecornis, C.constricta, Difflugia tuberculata, D.acuminata, D.lebes, D.oblonga, D.corona, D.urceollata, Difflugia sp., Lesquersia sprialis, L. modesta, Nebela sp, Phacus sp., Eunapius carteri and Diaptomus sp.). Low presence of metazooplankton and abundance of protozooplankton in many rivers has also earlier been reported $[4,8,36]$. Due to the often limited numeric importance of the riverine metazoans, composition and the control of plankton in rivers differ considerably from that in lentic waters [37].

Planktonic composition in the river Chenab and its tributaries (Rotifera 10 spp., Cladocera 5 spp. and Copepoda 2 spp.) reported in Indian segment [17] is different from the present observations at Akhnoor. Planktonic composition in the river Chenab is even different from the earlier observations from Banganga stream (38), Katra (2 species of Protozoa, 12 species of Rotifera and 1 species of Copepoda) and from Bishleri stream [15], Banihal (Protozoa: Difflugia, Centropyxis, Arcella and Glaucoma; Rotifera: Brachionus, Colurella, Euchlanis, Keratella, Lepadella, Monostyla, Notholca and Trichocerca; Cladocera: Alona and Chydorus; and Copepoda: Cyclops and nauplius larva) two important 
tributaries of the river Chenab. Presence of Rotifera, Cladocera and Copepoda reported earlier [15, 17, 38] in various tributaries joining the river Chenab, upstream Akhnoor, and their absence at Akhnoor may be due to their non-survival in torrential water of the river Chenab.

Present zooplanktonic diversity in the river Chenab is even different from the earlier observations made from the river Tawi, an important tributary of the river Chenab, joining in Pakistan. Zutshi [13] observed 6 species of Protozoa, 3 species of Rotifera, 2 species of Cladocera, 3 species of Copepoda, Ephemeroptera, Diptera, Trichoptera, Oligochaeta and Nematoda at the non-polluted Nagrota bypass station of the river Tawi. At the polluted Bhagwati nagar station, she identified Protozoa (12 species), Rotifera (6 species) and one species each of Copepoda, Oligochaete, Ostracoda, Ephemeroptera, Nematoda and Archnida. Sawhney [14] noticed 15 species of Protozoa, 3 species of Rotifera, one species of Gastroricha and 1 species of Cladocera from the river Tawi at Nagrota bypass, Jammu. Dutta [19] noticed 56 species of zooplankton belonging to protozoa (35 species), Arthropoda (8 species), Rotifera (7 species), Annelida (3 species), Turbellaria (1 species), water Nematoda and cysts from Behar Devta, Udhampur, to Bhagwati Nagar, Jammu. At non-polluted Behar Devta, Udhampur, zooplankton belonging to Protozoa (19 species), Rotifera (3 species), Copepoda (1 species), Cladocera (ephippium) and Ephemeroptera were observed. Among 14 zooplanktonic species collected at Nagrota bypass station, 13 species of Protozoa and 1 species of Annelida made their presence. Only 10 species of Protozoa were netted at non polluted Hari ki Pohri station, Jammu. At the highly polluted Bhagwati Nagar station, in Jammu city, rich diversified zooplankton was represented by Protozoa (35 species), Rotifera (7 species), Ostracoda (4 species), Annelida (3 species), Diptera (1 species), Cladocera (1 species and ephippum), Turbellaria (1 species), water Nematoda and cysts.

Zooplanktonic diversity in the river Chenab at Akhnoor, India, is different from its Pakistan segment. Chughtai et al. [39] reported Protozoa (Holophrya, Didinium, Euglypha, Tintinnopsis, Hemiophrys, Amoeba, Centropyxis, Pseudodifflugia, Difflugia, Arcella, Paramecium, Cyphoderra), Rotifera (Asplanchna, Ascomorpha, Epiphanes, Colurella, Dicranophorus) and Cladocera (Daphnia) from Multan area. Khan et al. [40] analysed zooplankton of the river Chenab at Marala, Punjab, Pakistan, and enlisted Protozoa (Arcella artocrae, Difflugia lobostoma, Centropyxis aculeta and Paulinella nidulus), Bryozoa (Plumatella fruiticosa and Fredericella sultana), Rotifera (Polyarthra vulgaris, Filinia longiseta, F. minuta, Keratella quadrata, K. cochlaeris, Asplanchna priodonta, Epiphanes branchionus, Euclanis dilatata, Trichosphera solstialis and Philodina roseola), Copepoda (Osphranticum labronectum, Diaptomus castor, D. sarsi, Cyclops viridus, C. varicans, Mesocyclops leuckarti, M. hyalinus and Parastenocaris lacustris), Cladocera (Daphnia ambigua, Ceriodaphnia reticulata, Moinadaphnia malcayii, Daphnia smilis, Bosmina longirostris, Macrothrix rosae, Chydorus poppi and Alona rectangula) and Ostracoda (Cyclocypris globosa). Bhatti et al [41] surveyed zooplankton of Jammu Tawi, Chenab river and Manwar Tawi, creating Marala wetlands complex, Pakistan, and noticed Protozoa (Amoeba, Paramecium, Vorticella, Stentor, Astria, Euglena, Euplotes), Crustacea (Daphnia, Moina, Scapholabaris, Cyclops, Diaptomus and Ostracoda), Rotifera (Brachionus, Platyias, Asplanchna and Philodina) and insects (mosquito larvae, water spider, dragonflies, Covina sp., demsalfly nymph, mayfly nymph, Culex larvae and Chironomus larvae). Earlier, Eddy [42] also observed low zooplanktonic diversity dominated by protozoans in the upper 50 miles of Sangamon river, Illinois, and diversified zooplankton in the lower portions.

Poor zooplanktonic diversity observed in the Indian segment of the river Chenab, at Akhnoor, may be due to:-

1) Torrential flow and absence of slack water habitats. The latter have fast population growth rates for plankton [5, 31-34)

2) Wide fluctuations in water discharge and turbidity. Water discharge in the river Chenab is very high and highly turbid during spring, summer and monsoon. It is reduced and less turbid during winter season. According to Pace et al. [2], Basu and Pick [31] and Thorp and Casper [43], zooplankton community structure in rivers is controlled primarily by hydrodynamic forces and suspended matter. Hart [44, 45] mentioned that inorganic turbidity affects zooplankton filtration and development rates. Pourriot et al. [46] analysed zooplankton of the river Marne, France, and reported a decline in the area where turbidity increases. According to Karr [47] and Poff et al. [48], the five components of the flow regime (magnitude, frequency, duration, timing and rate of change) influence the ecological dynamics of river system directly or indirectly through their effects on other primary regulators.

3) Riverine environment is considered challenging for zooplankton for three reasons [49]:

(I) water currents may transport zooplankton downstream before they can reproduce and replenish upstream stocks (II) physical stress from turbulence in lotic systems (decreasing with stream size) and other physical factors which reduce fecundity and survival chances of individuals and (III) net production of microalgae (primary food base for zooplankton) is diminished both by the helical flow of water which takes the algae below the photic zone for significant periods and by high inorganic turbidity that further interferes with consumption of diminished algal stocks.

4) Poor food quality may constrain zooplanktonic diversity in the fast flowing river Chenab. Food is available as allochthonous sestonic organic matter and is not utilized by diversified zooplankton. High concentrations of nonalgal seston may have deleterious effects on riverine zooplankton, either directly by interfering with feeding mechanisms $[2,50,51]$ or indirectly by diluting the intake of nutritionally important dietary elements like $\mathrm{N}$. P. fatty acids and lipids [52]. 
5) Absence of macrophytic vegetation, which is known to offer suitable habitat and even retain zooplankton [53, 54].

6) Absence of water pollution $[13,19]$

Monthly mean zooplanktonic analysis has shown irregular records during two years of present study (Tables $1 \& 2$ ).

During the year 2009-2010, among various genera of Rhizopoda, a dominant group of zooplankton in the river Chenab, genus Difflugia recorded its perennial presence. Among its different species, Difflugia bacillifera (April-June and December) was observed four times; Difflugia sp. (March - June, August and December - February), D. corona (March - June, August, September, December and February) and D. rubescens (April, May, July, September and November- February) eight times; D. urocellata (March-May and September - February) and D. tuberculata (March-May, July-September, November, December and February) nine times. Perennial presence is shown by D. lebes (except in November), D. acuminata and D. oblonga (Table 1).

Genus Arcella observed its eleven times presence. Among its various species, A. vulgaris was noticed nine times (March, April, May, July and October-February) and $A$. discoides five times viz. March, June, July, August and February. (Table 1).

Among various species of Centropyxis, which recorded ten times presence, C. aerophila (April, September and February) was seen thrice; $C$. arcelloides (March, September, October and December-February) six times; C. constricta (MarchMay, September and November-January) seven times and $C$. ecornis ( March, April and September - February) eight times.

Genus Lesquersia made its perennial record (except in October) in the zooplanktonic samples analysed from the river Chenab. Among its various species L. spiralis (March, June, August, September and November to February) and $L$. modesta (March-May, July, August and November-Februrary) showed their ten and nine times presence, respectively. Genus Plagiopyxis was seen in March and Nebela in March, April, June and September only.

Among Mastigophora, Euglenasp. was seen in the month of December and Phacus sp. in the month of March, April, July and November. (Table 1).

Haltaria sp., a Suctoria, was noticed in the month of March.

Gemmules of Spongilla lacustris were observed in the month of March, May and February and Eunapius carteri in the month of March and February.

Planaria sp. was noticed in the month of December and January (Table 1).

During the second year of study viz. March, 2010February 2011, genus Diffugia remained perennial. Among its various species, Diffugia oblonga, D.acuminata (except in October) and D.tuberculata (except in June) remained perennial in the samples collected from the river Chenab. Diffiluiga bacillifera was seen once (April); Diffugia sp. four times (April, May, August and January). D. corona six times (March, May, July, August, November and February); D. rubscens (March-May and September-January) and $D$. urocellata (April, July and September- February) eight times and D.lebes (March-May, July-October and DecemberFebruary) ten times (Table 2).

Arcella discoides (March, May, July, October, December and January) and A. vulgaris (April and May) were seen six times and twice respectively, among the planktonic samples of the river Chenab.

Genus Centropyxis recorded June-August and October absence. Among its various species Centropyxis aercelloides was seen twice (March and December); C. aerophila four times (September and December to February); C. ecornis (March, April and November -January) and C. aculeata (March, April, and November-January) five times and $C$. constricta (March, May and November-February) six times.

Among various species of Lesquersia, L. spiralis (March, May, July - January) and L. modesta (March, April, JulySeptember and November to February) were noticed nine times in the planktonic samples of the river Chenab (Table 2).

Among other genera of Rhizopoda, Plagiopyxis (April) was recorded once andNebela (March-May) thrice.

Genus Phacus, among class Mastigophora, was seen five times viz. March, April, July, November and December.

Paramecium, a Ciliate, was netted during DecemberFebruary. Haltaria, among Suctoria, was noticed four times (March and November-January).

Gemmules of Euanapius carteri (May and February) and Spongilla lacustris (March and May) were observed twice in planktonic samples.

Planaria was recorded only once in the month of January. (Table 1)

In the year, 2009-10, zooplanktonic qualitative diversity was high during March-May and December-February and irregular and low during June-November. These recorded March maximum and October minimum qualitative count (Table 1).

Zooplanktonic diversity in the year 2010-11 was high during March-May and December and January and irregular during June to November and February. These recorded maximum diversity in the month of March, December and January and minimum in the month of June (Tables $1 \& 2$ ).

\subsubsection{Quantitative Analysis}

Quantitatively, during the year 2009-2010, total zooplankton, protozoans, poriferans and turbellarians varied between 8-36 n/1, 8-36 n/l, 0-2 n/1 and 0-1 n/1, respectively. (Table 1)

Among different groups of protozoans, there is quantitative dominance of Rhizopoda (8-35 n/l) and subdominance of Mastigophora (0-1 n/l) and Suctoria (0-1 $\mathrm{n} / \mathrm{l})$.

The order of dominance of different genera of Rhizopoda has been observed as Diffugia (4-23 n/l) $\geq$ Centropyxis $(0-8$ $\mathrm{n} / \mathrm{l}) \geq$ Lesquersia $(0-6 \mathrm{n} / \mathrm{l}) \geq$ Arcella $(0-2 \mathrm{n} / \mathrm{l})$ and $\geq \operatorname{Nebela}(0-1$ $\mathrm{n} / \mathrm{l})$ and $\geq$ Plagiopyxis $(0-1 \mathrm{n} / \mathrm{l})$. Haltaria, a Suctoria, is noticed only once in March $(1 \mathrm{n} / \mathrm{l})$. Spongilla lacustris and Eunapius carteri gemmules varied between 0-1 n/l. 
Plainaria, a Turbellaria, was seen in the month of December (1 n/l) and January (1 n/l).

During the year 2010-11, quantitatively, mean total zooplankton, Protozoa, Porifera and Turbellaria count varied between 3-30 n/1, 3-30 n/1, 0-2 n/1 and 0-1 n/l, respectively (Table 2).

Quantitatively, among various genera of Rhizopoda, the most dominant group, there was dominance of Difflugia (3$18 \mathrm{n} / \mathrm{l})$ followed by Centropyxis (0-9 n/1), Lesquersia (0-4 $\mathrm{n} / 1)$. Arcella $(0-2 \mathrm{n} / 1)$ and Plagiopyxis $(0-1 \mathrm{n} / 1)$ andNebela $(0-$ $1 \mathrm{n} / \mathrm{l})$.

Phacus, among Mastigophora, was seen in the month of March (1 n/l), April (1 n/l), July ( $1 \mathrm{n} / \mathrm{l})$, November (1 n/l) and December $(1 \mathrm{n} / \mathrm{l})$. Quantitative count of Paramecium, $a$ Ciliate, varied between 0-2 n/l. Haltaria, a Suctoria, varied between $0-2 \mathrm{n} / 1$.

Among Porifera, Spongilla lacustris was recorded in the month of March (1 n/l) and May (1 n/l) and Eunapis carteri in the month of May $(1 \mathrm{n} / \mathrm{l})$ and February $(1 \mathrm{n} / \mathrm{l})$.

Planaria, a turbellarian, showed its presence in the month of January (1 $\mathrm{n} / \mathrm{l})$.

An overall qualitative and quantitative analysis has shown dominance of rhizopod protozoans and may be due to the presence of protective shells.

In the river Chenab, zooplanktonic quantitative count in the year 2009-10 was high during March-April and December, with maximum count in the month of April and minimum in the month of October (Table 1). In the year 2010-11, total zooplankton was high during March-May and November-January. These recorded December maximum and June minimum count (Table 2). Zooplankton mostly remained low and irregular during monsoon and post monsoon during both the years. This is in agreement to the findings of earlier workers [13, 15-19, 55-59] for various lotic waters. Contrary to this, Bhatti et al. (41) reported monsoon maximum record of zooplankton from Marala wetlands complex, Pakistan. Monsoon viz. June- September low diversity and density of zooplankton is caused by floods, high turbidity and suspended matter, low transparency, wide spread of water and dilution caused by heavy rains in the catchment.

March to May rise in zooplanktonic count is due to increase in water level and flooding of rock pools, after winter exposure, and flushing of zooplankton in the river. Rock pools analysis has shown more diversified and rich zooplankton in comparison to the Chenab river [35]. Clear water, low turbidity and suspended matter, reduced water flow and low water spread may account for winter rise in zooplanktonic diversity and density. Zooplanktonic increase as observed in the Chenab during winter low flow is in agreement with the earlier observations [60].

Analysis of coefficient of correlation $(\gamma)$ of total zooplankton, during the year 2009-2010 / 2010-2011, with water quality parameters viz. air temperature $(\gamma=-.098)$, water temperature $(\gamma=-0.293)$, depth $(\gamma=-0.291)$, transparency $(\gamma=-$ $0.039)$, turbidity $(\gamma=-0.245)$, suspended matter $(\gamma=-0.064)$, $\mathrm{pH}(\gamma=-0.636)$, conductivity $(\gamma=-0.019)$, total dissolved solids $(\gamma=-0.120)$, salinity $(\gamma=-0.521)$, dissolved oxygen $(\gamma=0.700)$, BOD $\quad(\gamma=0.469), \quad$ carbonate $\quad(\gamma=-\quad 0.268)$, bicarbonate $(\gamma=0.260)$, chloride $(\gamma=0.450)$, calcium $(\gamma=0.202)$, magnesium $(\gamma=-0.166)$, total hardness $(\gamma=0.066)$, sodium $(\gamma=0.443)$, potassium $(\gamma=-0.602)$, phosphate $(\gamma=-0.169)$, nitrate $(\gamma=-0.319)$, silicate $(\gamma=-0.446)$ and sulphate $(\gamma=0.067)$ / air temperature $(\gamma=0.411)$, water temperature $(\gamma=-0.519)$, depth $(\gamma=-0.420)$, transparency $(\gamma=-0.322)$, turbidity $(\gamma=-$ $0.445)$, suspended matter $(\gamma=-0.044)$, $\mathrm{pH} \quad(\gamma=0.405)$, conductivity $(\gamma=-0.118)$, total dissolved solids $(\gamma=0.148)$, salinity $(\gamma=0.339)$, dissolved oxygen $(\gamma=0.122)$, BOD $(\gamma=-$ $0.517)$, carbonate $(\gamma=0.402)$, bicarbonate $(\gamma=0.137)$, chloride $(\gamma=0.142)$, calcium $(\gamma=0.239)$, magnesium $(\gamma=-0.056)$, total hardness $(\gamma=0.184)$, sodium $(\gamma=-0.389)$, potassium $(\gamma=-$ $0.418)$, phosphate $(\gamma=0.195)$, nitrate $(\gamma=0.216)$, silicate $(\gamma=-$ $0.281)$ and suphate $(\gamma=0.565)$ is almost insignificant. This indicates that no single factor is a strong determinant for zooplanktonic abundance in the river Chenab and is in agreement to earlier findings $[16-19,57]$.

\section{Conclusion}

The Chenab River is a major river that flows in uplands of India and plains of Pakistan. It is formed by confluence of two headwaters, Chandra and Bhaga, which rise in the upper Himalayas in the Lahaul and Spiti district of Himachal Pradesh state, India. Chenab flows through Jammu region of Union Territory of Jammu and Kashmir, India, into the plains of Punjab, Pakistan, before flowing into the Indus river near the city of Uch Sharif. A total of 28 zooplanktonic species belonging to 25 species of protozoa, gemmules of 2 species of Porifera (Spongilla lacustris and Eunapius carteri) and 1 species of Turbellaria (Planaria sp.) were noticed. These have their origin (i) mainly in surface rockpools (ii) in tributaries joining the river Chenab upstream Akhnoor and (iii) a part is periphytonic (epilithic/ epibenthic) and gets dislodged by strong currents of river water. Qualitative analysis of zooplankton of the torrential river Chenab, in the Indian segment, at Akhnoor has shown the dominance of Protozoa ( 25 species) followed by gemmules of Porifera (2 species) and Turbelleria (1 species). There is no change in qualitative composition of zooplankton from the earlier observation. Zooplanktonic diversity in slow moving and polluted segment of river Chenab, in Pakistan, is more diversified and is dominated by metazoans. Zooplanktonic diversity and density is low at Akhnoor during monsoon and post monsoon seasons. Analysis of coefficient of correlation of zooplankton with various water quality parameters is insignificant. 
Table 1. Monthly mean qualitative composition and quantitative analysis (number/lt) of Zooplankton at Station I, II, III of the River Chenab at Akhnoor, Jammu. (March, 2009-February, 2010).

\begin{tabular}{|c|c|c|c|c|c|c|c|c|c|c|c|c|}
\hline & $\mathbf{M}$ & $\mathbf{A}$ & $\mathbf{M}$ & $\mathbf{J}$ & $\mathbf{J}$ & $\mathbf{A}$ & $\mathbf{S}$ & $\mathbf{O}$ & $\mathbf{N}$ & D & $\mathbf{J}$ & $\mathbf{F}$ \\
\hline \multicolumn{13}{|l|}{ Organism } \\
\hline \multicolumn{13}{|l|}{ Protozoa } \\
\hline \multicolumn{13}{|l|}{ Sarcodina } \\
\hline \multicolumn{13}{|l|}{ Rhizophoda } \\
\hline Arcella discoides Ehrenberg & 1 & - & - & 1 & 1 & 1 & - & - & - & - & - & 1 \\
\hline A. vulgaris Ehrenberg & 1 & 1 & 1 & - & 1 & - & - & 1 & 1 & 2 & 1 & 1 \\
\hline Total Arcella & 2 & 1 & 1 & 1 & 2 & 1 & - & 1 & 1 & 2 & 1 & 2 \\
\hline Centropyxis ecornis Ehrenberg & 2 & 3 & - & - & - & - & 1 & 2 & 2 & 1 & 1 & 1 \\
\hline C. aculeata Ehrenberg & 1 & 1 & 1 & - & 1 & - & - & - & 2 & 1 & 3 & 1 \\
\hline C. aerophila Deflander & - & 1 & - & - & - & - & 2 & - & - & - & - & 1 \\
\hline C. constricta Penard & 1 & 3 & 1 & - & - & - & 1 & - & 1 & 2 & 2 & - \\
\hline C. arcelloides Penard & 1 & - & - & - & - & - & 1 & 1 & - & 1 & 1 & 1 \\
\hline Total Centropyxis & 5 & 8 & $2-$ & - & 1 & - & 5 & 3 & 5 & 5 & 7 & 4 \\
\hline Difflugia tuberculata Wallich & 2 & 6 & 2 & - & 3 & 1 & 2 & - & 2 & 3 & - & 1 \\
\hline D. accuminata Ehrenberg & 1 & 3 & 3 & 1 & 4 & 2 & 1 & 1 & 2 & 2 & 2 & 2 \\
\hline D. lebes Penard & 2 & 2 & 1 & 1 & 1 & 1 & 1 & 1 & - & 1 & 1 & 2 \\
\hline D. oblonga Ehrenberg & 2 & 3 & 4 & 2 & 4 & 4 & 7 & 1 & 4 & 6 & 3 & 2 \\
\hline D. corona Wallich & 1 & 4 & 1 & 1 & - & 1 & 1 & - & - & 2 & - & 1 \\
\hline Difflugia $s p$. & 1 & 2 & 1 & 1 & - & 1 & - & - & - & 1 & 1 & 1 \\
\hline D urocelata Carter & 1 & 1 & 1 & - & - & - & 1 & 1 & 1 & 2 & 1 & 1 \\
\hline D. bacillifera Penard & - & 1 & 1 & 1 & - & - & - & - & - & - & 1 & - \\
\hline D. rubescens Penard & - & 1 & 1 & - & 2 & - & 1 & - & 2 & 2 & 1 & 1 \\
\hline Total Difflugia & 10 & 23 & 15 & 7 & 14 & 9 & 14 & 4 & 11 & 19 & 10 & 11 \\
\hline Lesquereusia modesta Rhumbler & 1 & 1 & 1 & - & 5 & 5 & - & - & 1 & 2 & 1 & 1 \\
\hline L. spiralis Ehrenberg & 1 & 1 & 1 & 1 & - & 1 & 1 & - & 1 & 2 & 1 & 1 \\
\hline Total Lesquereusia & 2 & 2 & 2 & 1 & 5 & 6 & 1 & - & 2 & 4 & 2 & 2 \\
\hline Plagiopyxis Penard & 1 & - & - & - & - & - & - & - & - & - & - & - \\
\hline Nebela Leidy & 1 & 1 & - & 1 & - & - & 1 & - & - & - & - & - \\
\hline Euglypha Dujardin & - & - & - & - & - & - & - & - & - & - & - & - \\
\hline Total Rhizophoda & 21 & 35 & 20 & 10 & 22 & 16 & 21 & 8 & 19 & 30 & 20 & 19 \\
\hline \multicolumn{13}{|l|}{ Mastigophora } \\
\hline Euglena Ehrenberg & - & - & - & - & - & - & - & - & & 1 & - & - \\
\hline Phacus Dujardin & 1 & 1 & - & - & 1 & - & - & - & 1 & - & - & - \\
\hline Total Mastigophora & 1 & 1 & - & - & 1 & - & - & - & 1 & - & - & - \\
\hline \multicolumn{13}{|l|}{ Ciliata } \\
\hline $\begin{array}{l}\text { Paramecium Hill } \\
\text { Suctoria }\end{array}$ & - & - & - & - & - & - & - & - & - & - & - & - \\
\hline $\begin{array}{l}\text { Suctoria } \\
\text { Haltaria Dujardin }\end{array}$ & \multicolumn{8}{|c|}{ Suctoria } & & & & \\
\hline $\begin{array}{l}\text { Haltaria Dujardın } \\
\text { Total Protozoa }\end{array}$ & 1 & - & - & - & - & it & - & - & - & - & - & - \\
\hline \multicolumn{13}{|l|}{ Porifera } \\
\hline Spongilla lacustris Linnaeus & 1 & - & 1 & - & - & - & - & - & - & - & - & 1 \\
\hline Eunapius carteri Carter & 1 & - & - & - & - & - & - & - & - & - & - & 1 \\
\hline Total Porifera & 2 & - & 1 & - & - & - & - & - & - & - & - & 2 \\
\hline \multicolumn{13}{|l|}{ Turbellaria } \\
\hline Planaria & - & - & - & - & - & - & - & - & - & 1 & 1 & - \\
\hline Total zooplankton & 25 & 36 & 21 & 10 & 23 & 16 & 21 & 8 & 20 & 32 & 21 & 21 \\
\hline
\end{tabular}

Table 2. Monthly mean qualitative composition and quantitative analysis (number/lt) of Zooplankton at Station I, II and III, Dhoomi, of the River Chenab at Akhnoor, Jammu. (March, 2010-February 2011).

\begin{tabular}{|c|c|c|c|c|c|c|c|c|c|c|c|c|}
\hline & M & $\mathbf{A}$ & M & $\mathbf{J}$ & $\mathbf{J}$ & $\mathbf{A}$ & $\mathbf{S}$ & $\mathbf{O}$ & $\mathbf{N}$ & D & $\mathbf{J}$ & $\mathbf{F}$ \\
\hline \multicolumn{13}{|l|}{ Organism } \\
\hline \multicolumn{13}{|l|}{ Protozoa } \\
\hline \multicolumn{13}{|l|}{ Sarcodina } \\
\hline \multicolumn{13}{|l|}{ Rhizophoda } \\
\hline Arcella discoides Ehrenberg & 1 & - & 1 & - & 1 & - & - & 1 & - & 1 & 1 & - \\
\hline A. vulgaris Ehrenberg & - & 1 & 1 & - & - & - & - & - & - & - & - & - \\
\hline Total Arcella & 1 & 1 & 2 & 0 & 1 & 0 & 0 & 1 & 0 & 1 & 1 & 0 \\
\hline Centropyxis ecornis Ehrenberg & 1 & 1 & - & - & - & - & - & - & 4 & 2 & 2 & - \\
\hline C. aculeata Ehrenberg & 1 & 1 & - & - & - & - & - & - & 4 & 1 & 1 & - \\
\hline C. aerophila Deflander & - & - & - & - & - & - & 1 & - & - & 2 & 1 & 1 \\
\hline C. constricta Penard & 1 & - & 1 & - & - & - & - & - & 1 & 3 & 1 & 1 \\
\hline C. arcelloides Penard & 1 & - & - & - & - & - & - & - & - & 1 & - & - \\
\hline Total Centropyxis & 4 & 2 & 1 & - & - & - & 1 & - & 9 & 9 & 5 & 2 \\
\hline Difflugia tuberculata Wallich & 1 & 3 & 5 & - & 2 & 3 & 1 & 2 & 2 & 1 & 1 & 1 \\
\hline
\end{tabular}




\begin{tabular}{|c|c|c|c|c|c|c|c|c|c|c|c|c|}
\hline & M & $\mathbf{A}$ & $\mathbf{M}$ & $\mathbf{J}$ & $\mathbf{J}$ & $\mathbf{A}$ & $\mathbf{S}$ & $\mathbf{O}$ & $\mathbf{N}$ & D & $\mathbf{J}$ & $\mathbf{F}$ \\
\hline D. accuminata Ehrenberg & 1 & 3 & 2 & 1 & 2 & 1 & 1 & - & 1 & 2 & 1 & 1 \\
\hline D. lebes Penard & 1 & 1 & 2 & - & 1 & 1 & 1 & 1 & - & 4 & 1 & 1 \\
\hline D. oblonga Ehrenberg & 1 & 4 & 3 & 1 & 3 & 5 & 3 & 2 & 3 & 3 & 4 & 3 \\
\hline D. corona Wallich & 1 & - & 1 & - & 1 & 1 & - & - & 1 & - & - & 1 \\
\hline Difflugia $s p$. & - & 3 & 1 & - & - & 1 & - & - & - & - & 1 & - \\
\hline D urocelata Carter & - & 1 & - & 1 & - & - & 1 & 1 & 1 & 2 & 1 & 1 \\
\hline D. bacillifera Penard & - & 1 & - & - & - & - & - & - & - & - & - & - \\
\hline D. rubescens Penard & 1 & 2 & 1 & - & - & - & 1 & 1 & 2 & 3 & 1 & - \\
\hline Total Difflugia & 6 & 18 & 15 & 3 & 9 & 12 & 8 & 7 & 10 & 15 & 10 & 8 \\
\hline Lesquereusia modesta Rhumbler & 1 & 1 & - & - & 2 & 2 & 1 & - & 1 & 1 & 2 & 1 \\
\hline L. spiralis Ehrenberg & 1 & - & 1 & - & 2 & 2 & 1 & 1 & 1 & 1 & 1 & - \\
\hline Total Lesquereusia & 2 & 1 & 1 & - & 4 & 4 & 2 & 1 & 2 & 2 & 3 & - \\
\hline Plagiopyxis Penard & - & 1 & - & - & - & - & - & - & - & - & - & - \\
\hline Nebela Leidy & 1 & 1 & 1 & - & - & - & - & - & - & - & - & - \\
\hline Euglypha Dujardin & - & - & - & - & - & - & - & - & - & - & - & - \\
\hline $\begin{array}{l}\text { Total Rhizophoda } \\
\text { Mastigophora }\end{array}$ & 16 & 24 & 20 & 3 & 14 & 16 & 11 & 9 & 21 & 27 & 19 & 11 \\
\hline Euglena Ehrenberg & - & - & - & - & - & - & - & - & - & - & - & - \\
\hline Phacus Dujardin & 1 & 1 & - & - & 1 & - & - & - & 1 & 1 & - & - \\
\hline Total Mastigophora & 1 & 1 & - & - & 1 & - & - & - & 1 & 1 & - & - \\
\hline Ciliata & - & - & - & - & - & - & - & - & - & - & - & - \\
\hline $\begin{array}{l}\text { Paramecium Hill } \\
\text { Suctoria }\end{array}$ & - & - & - & - & - & - & - & - & - & 2 & 1 & 1 \\
\hline Haltaria Dujardin & 2 & - & - & - & - & - & - & - & 1 & 1 & 1 & - \\
\hline $\begin{array}{l}\text { Total Protozoa } \\
\text { Porifera }\end{array}$ & 18 & 25 & 20 & 3 & 15 & 16 & 11 & 9 & 21 & 30 & 21 & 11 \\
\hline Spongilla lacustris Linnaeus & 1 & - & 1 & - & - & - & - & - & - & - & - & - \\
\hline Eunapius carteri Carter & - & - & 1 & - & - & - & - & - & - & - & - & 1 \\
\hline $\begin{array}{l}\text { Total Porifera } \\
\text { Turbellaria }\end{array}$ & 1 & - & 2 & - & - & - & - & - & - & - & - & 1 \\
\hline Planaria & - & - & - & - & - & - & - & - & - & - & 1 & - \\
\hline Total zooplankton & 19 & 25 & 22 & 3 & 15 & 16 & 11 & 9 & 21 & 30 & 22 & 12 \\
\hline
\end{tabular}

\section{Acknowledgements}

This paper is a part of the project supported by the UGC, New Delhi, and is gratefully acknowledged. HOD, Environmental Sciences, University of Jammu, Jammu, is acknowledged for providing necessary facilities in the department.

\section{References}

[1] J. F. III Saunders and W. M. Jr. Lewis, "Zooplankton abundance and transport in a tropical white-water river", Hydrobiologia, Vol. 162, pp 147-155, 1988a.

[2] M. L. Pace, S. E. G. Findlay and D. Lints, "Zooplankton in advective environments. The Hudson River community and a comparative analysis", Canadian Journal of Fisheries and Aquatic Sciences, Vol. 49, pp 1060-1069, 1992.

[3] J. H. Thorp, A. R. Black, K. H. Haag and J. D. Wehr, "Zooplankton assemblages in the Ohio River: seasonal tributary and navigation dam effects", Canadian Journal of Fisheries and Aquatic Sciences, Vol. 51, pp 1634-1643, 1994.

[4] M. Weitere, A. Scherwass, Karl-Theo Sieben and H. Arndt, "Planktonic food web structure and potential carbon flow in the lower river Rhine with a focus on the role of protozoans." River Research and Applications, Vol. 21, pp 535-549, 2005.

[5] C. S. Reynolds and J. P. Descy, "The production, biomass and structure of phytoplankton in large rivers", Archive Für Hydrobiologie supplement band, Vol. 113, pp 161-187, 1996.
[6] N. Lair, V. Jacquet and P. Reyes-Marchant, "Factors related to autotrophic potamoplankton, heterotrophic protists and micrometazoan abundance, at two sites in a lowland temperate river during low water flow", Hydrobiologia, Vol. 394, pp 1328, 1999.

[7] M. Weitere and H. Arndt, "Top down effects on pelagic heterotrophic nanoflagellates (HNF) in large River (Rhine): Do losses to the benthos play a role", Freshwater Biology, Vol. 47, pp 1437-1450, 2002a.

[8] M. Weitere and H. Arndt, "Water discharge regulatedbacteria/heterotrophic nanoflagellates (HNF) interactions in the water column of the River Rhine", Microbial Ecology, Vol. 44, pp 19-29, $2002 \mathrm{~b}$.

[9] R. Sanders, "Trophic strategies among heterotrophic flagellates. In: The biology of free living heterotrophic flagellates", Peterson, D. J. and Larsen, J. (eds.). Clarendon Press: Oxford; pp 21-38, 1991.

[10] E. B. Sherr and B. F. Sherr, "Bacterivory and herbivory: Keyroles of phagotrophic protists in pelagic food webs", Microbial Ecology, Vol. 28, pp 233-235, 1994.

[11] H. Arndt, D. Dietrich, B. Auer, E. J. Cleven, T. Grafenhän, M. Weitere, and A. P. Mylnikov, "Functional diversity of heterotrophic flagellates in the aquatic ecosystems". In the flagellates, Leadbeater, B. S. C. and Green, J. C. (eds), Taylor and Francis, London, pp 240-268, 2000.

[12] R. W. Howarth, R. Shneider, and D. Swaney, "Metabolism and organic carbon fluxes in the tidal freshwater Hudson River”, Estuaries, Vol. 19, pp 848-865, 1996. 
[13] N. Zutshi, "Effect of Jammu city sewage on abiotic and biotic factors of the river Tawi, Jammu", Ph.D Thesis, University of Jammu, Jammu, 1992.

[14] J. Sawhney, "Physico-chemical characteristics of water and plankton of river Tawi at Nagrota bypass, Jammu", M.Sc Dissertation, University of Jammu, Jammu, 1998.

[15] F. A. Faiaz, T. A. Qureshi, K. Borana, I. Joginder and M. Singh, "Qualitative abundance of zooplankton of Bishleri stream of Banihal, Doda (J \& K State)", Current World Environment, Vol. 1 (1), pp 151-152, 2006.

[16] A. Sharma, "Hydrobiology of river Basanter at Samba, Jammu", Ph.D Thesis, University of Jammu, Jammu, 2009.

[17] V. Rathore, "Hydrobiology of Uch River, Kathua (J\&K)", Ph.D Thesis, University of Jammu, Jammu, 2009.

[18] S. P. S. Dutta and K. K. Verma, "Zooplanktonic analysis of the river Chenab, at Akhnoor, Jammu", The Ecoscan, Vol. 4 (1), pp 123-128, 2010.

[19] S. P. S. Dutta, "Ecology of the river Tawi with reference to its pollution in Jammu city", Project report submitted to the Govt. of Jammu \& Kashmir, Deptt. of Ecology, Environment and Remote Sensing, 55 pp, 2012.

[20] D. I. Baba, K. K. Sharma, and K. Gupta "Zooplanktonic community structure of river Chenab of Jammu and Kashmir (J\&K)”, J. Sci., Vol. 5 (9), pp 776-780, 2015.

[21] K. N. Nair, B. K. Das and B. N. Mukherjee, "On some freshwater Rhizopoda and Helizoa (Protozoa) from Calcutta and Environments", Part 1. Rec. Zool. Surv. India, Vol. 65 (14), pp 1-16, 1971.

[22] R. W. Pennak, "Freshwater invertebrates of the United States", $2^{\text {nd }}$ Ed. John Wiley and Sons, New York, 803 pp, 1978.

[23] S. P. S Dutta, "On some freshwater Rhizopoda from Jammu Part - 1”, J. University Review (Science), Vol. 1, pp 91-94, 1983.

[24] R. R. Kudo, "Protozoology", Published by Books \& Periodicals Corp. (India), 1174 pp, 1986.

[25] W. T. Edmondson, "Fresh water Biology", John Wiley and Sons, New York, 1248 pp, 1992.

[26] C. A. Kofoid, "The plankton of Illinois River, 1804-1809, with introductory notes upon the hydrography of Illinois River and its basin. Part II Constituent organisms and their seasonal distribution", Bull. II. State Lab Nat. Hist., Vol. 8, pp 1-354, 1908.

[27] P. S. Galstoff "Limnological observations in the upper Mississippi, 1921”, Bull. U.S. Bur. Fish., Vol. 39, pp 347-438, 1924.

[28] W. Krieger, "Zur. Biologie des Flussplanktons", Pflanzenforschung, Vol. 10, 66 pp, 1927.

[29] R. W. Butcher, "Studies in the ecology of rivers II. The microflora of rivers with special reference to the algae on the riverbed”, Ann. Botany, Vol. 46, pp 813-861, 1932.

[30] A. V. Brown, R. I. Limbeck and M. D. Schram, "Trophic importance of zooplankton in streams with alluvial riffle and pool geomorphometry”, Archive. Für. Hydrobiologia, Vol. 114, pp 349-367, 1989.
[31] B. K. Basu and F. R. Pick, "Factors regulating phytoplankton and zooplankton biomass in temperate rivers", Limnology and Oceanography, Vol. 41, pp 1572-1577, 1996.

[32] W. Reckendorfer, H. Keckeih, G. Winkler and F. Schiemer, "Zooplankton abundance in the river Danube, Austria: the significance of inshore retention", Freshwater Biology, Vol. 41, pp 583-591, 1999.

[33] C. Baranyi, T. Hein, C. Holarek, S. Keckeis and F. Schiemer, "Zooplankton biomass and community structure in a Danube river flood plain system: effects of Hydrology", Freshwater Biology, Vol. 47, pp 473-482, 2002.

[34] B. K. Basu, J. Kalff and B. Pinel-Alloul, "The influence of macrophyte beds on plankton communities and their export from Fluvial lakes in the St. Lawrence river", Freshwater Biology, Vol. 45, pp 373-382, 2002.

[35] S. P. S. Dutta, "Limnology of rock pools in the river Chenab at Dhoomi, Akhnoor, in Jammu region of Union Territory of the Jammu and Kashmir", Journal of Applied and Natural Science, Vol. 12 (4), pp 599-606, 2020.

[36] M. Weitere and H. Arndt, "Structure of the heterotrophic flagellate community in the water column of the river Rhine (Germany)", European Journal of Protistology, Vol. 39, pp 287-300, 2003.

[37] E. C. Philips, "Composition of the zooplankton of a lake and stream in Northwest Arkansas", Journal of Freshwater Ecology, Vol. 10, pp 337-341, 1995.

[38] N. Sawhney, "Limnology of Ban Ganga stream with special reference to some consumers inhabiting the stream", M. Phil Dissertation, University of Jammu, Jammu, 2004.

[39] M. S. Chughtai, K. Mahmood and A. R. Awan, "Assessment of planktonic diversity in the river Chenab as affected by sewage of Multan city", Pak. J. Bot., Vol. 43 (5), pp 25512555,2011

[40] M. F. Khan, M. Afzal, A. Rab, M. R. Ali, R. Kausa and S. M. H. Mehdi, "Baseline studies on microinvertebrates of Head Marala, river Chenab, Punjab, Pakistan", Inter. J. Vet. Sc., Vol. 3 (4), pp 166-171, 2014.

[41] Z. Bhatti, M. A. Gondal, A. Ghufran and A. Batool, "Checklist of zooplankton in different rivers of Bajwat area", J. Biores. Manag., Vol. 5 (4), pp 9-13, 2018.

[42] S. Eddy, "The plankton of Sangamon River in the summer of 1929", State of Illionis. Div. Nat. Hist. Surv., Vol. 19, pp 469486, 1932.

[43] J. H. Thorp and A. F. Casper, "Importance of biotic interactions in large rivers: an experiment with planktivorous fish, dreissenid mussels and zooplankton in the St. Lawrence River", River Research and Application, Vol. 19, pp 265-279, 2003.

[44] R. C. Hart, "Zooplankton feeding rates in relation to suspended matter content: Potential influences on community structure in a turbid reservoir", Freshwater Biologie, Vol. 19, pp 123-139, 1988.

[45] R. C. Hart "Food and suspended sediment influences on the nauplair and copepodid durations of freshwater copepods: Comparative studies on Tropodiaptomus and Metadiaptomus", Journal of Plankton Research, Vol. 12, pp 345-363, 1991. 
[46] R. Pourriot, C. Rougler and A. Miquelis, "Origin and development of river zooplankton: example of the Marne", Hydrobilogia, Vol. 345, pp 143-148, 1997.

[47] J. R. Karr, "Biological integrity: A long - neglected aspect of water resource management". Ecological Applications, Vol. 1, pp 66-84, 1991.

[48] N. L. Poff, J. D. Allan, M. B. Bain, J. R. Karr, K. L. Prestegaard, B. D. Richter, R. E. Sparks and J. C. Stromberg, "The natural flow regime: a paradigm for river conservation and restoration", Bio-Sciences, Vol. 47, pp 769-784, 1997.

[49] A. F. Casper and J. H. Thorp, "Diel and lateral patterns of zooplankton distribution in the ST. Lawrence River", Riv. Res. Applic., Vol. 23, pp 73-85, 2007.

[50] J. F. III Saunders and W. M. Jr. Lewis, "Zooplankton abundance in the Caura River, Venezuela", Biotropica, Vol. 20, pp 206-214, 1988b.

[51] J. D. Jack, S. A. Toalson and J. J. Gilbert, "The effect of clays on a freshwater plankton community: an enclosure experiment", Archive. Für. Hydrobiologie, Vol. 127, pp 257270, 1993.

[52] D. L. Guelda, R. W. Koch, J. D. Jack and P. A. Bukaveckas, "Experimental evidence for density dependent effects and the importance of algal production in determining population growth rates of riverine zooplankton", River Research and Applications, Vol. 21, pp 595-608, 2005.

[53] S. K. Hamilton, S. J. Slipper, W. M. Lewis, and J. F. Saunders, "Zooplankton abundance and evidence for its reduction by macrophyte mats into Orinoca flood plain lakes", J. Plankton Research, Vol. 12, pp 345-367, 1990.
[54] C. Nilson, G. Grelsson, M. P. Johanson and U. Sprens, "Patterns of plant species richness along river banks", Ecology, Vol. 70, pp 71-84, 1989.

[55] H. Joshi, S. K. Shishodia, S. N. Kumar, D. K Sailia, B. P. Naijriyal, R. P. Mathur, P. K. Pande, B. S. Mathur, and N. Puri, "Ecosystems studies of upper region of Ganga River, India", Environ. Monit. and Assess., Vol. 35, pp 181-206, 1995.

[56] J. Sharma, "Effect of Industrial wastes and sewage on abiotic and biotic (planktons and macrophytes) components of Behlol nullah, Jammu", P.hD Thesis, University of Jammu, Jammu, 1999.

[57] N. K. Aggarwal and B. L. Thapilyal "Preimpoudment hydrological study of Bhilanganga River from Tehri dam reservoir area in Uttranchal", Environ. Geochem., Vol. 8, pp 143-148, 2005.

[58] D. R. Khanna, R. Bhutiani, G. Matta, V. Singh and G. Bhadauriya, "Study of planktonic diversity of river Ganga from Devprayag to Rourkee, Uttrakhand, India", Environment Conservation Journal, Vol. 13 (1-2), pp 211-217, 2012.

[59] A. Kumar, D. R. Khanna and R. Bhutiani, "Seasonal variations in physico-chemical parameters of river Beas, Himachal Pradesh, with special reference to planktonic population", Environment Conservation Journal, Vol. 16 (3), pp 127-131, 2015.

[60] L. De Cabo, A. Puig, S. Arreghini, H. F. Olguin, R. Seoane and I. Obertello, "Physico-chemical variables and plankton from the lower delta of the Parana River (Argentina) in relation to flow", Hydrobiological Processes, Vol. 17, pp 1279-1290, 2003. 